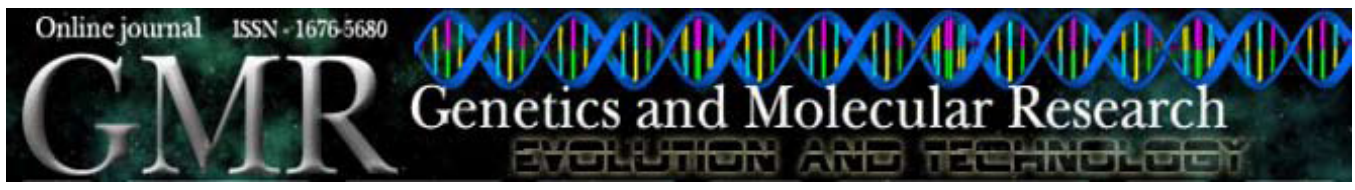

\title{
Molecular detection of ochratoxigenic Aspergillus species isolated from coffee beans in Saudi Arabia
}

\author{
M.A. Moslem ${ }^{1}$, A. Mashraqi ${ }^{1}$, K.A. Abd-Elsalam ${ }^{1,2}$, A.H. Bahkali ${ }^{1}$ and \\ M.A. Elnagaer ${ }^{3}$ \\ ${ }^{1}$ King Saud University, College of Science, \\ Botany and Microbiology Department, Riyadh, Saudi Arabia \\ ${ }^{2}$ King Saud University, College of Science, \\ Abdul Rahman Al-Jeraisy DNA Research Chair, Riyadh, Saudi Arabia \\ ${ }^{3}$ GSFMO, Research Central Laboratory, Riyadh \\ Corresponding author: K.A. Abd-Elsalam \\ E-mail:kamel200@ksu.edu.sa
}

Genet. Mol. Res. 9 (4): 2292-2299 (2010)

Received August 8, 2010

Accepted September 13, 2010

Published November 23, 2010

DOI 10.4238/vol9-4gmr943

\begin{abstract}
Ten fungal isolates from coffee beans were morphologically identified as Aspergillus niger, A. ochraceus and A. carbonarius $(\mathrm{N}=5,3$, and 2, respectively). Only one isolate, morphologically identified as $A$. niger, was unable to produce ochratoxin A (OTA). This may be a new species in the Aspergillus section Nigri. OTA levels in all the other isolates were above the limit of detection $(0.15 \mathrm{mg} / \mathrm{kg})$. Based on microsatellite-primed PCR (MP-PCR) profiles, using three microsatellite primers, three main groups were obtained by UPGMA cluster analysis: A. niger, A. ochraceus and A. carbonarius. A clear-cut association was found between the MP-PCR genotype and the ability to produce OTA. Using the primer pairs OCRA1/OCRA2, a single fragment of about $400 \mathrm{bp}$ was amplified only when genomic DNA from the A. ochraceus isolates was used.
\end{abstract}

Key words: Aspergillus; Ochratoxin; Coffea arabica 


\section{INTRODUCTION}

Aspergillus is one of the most important filamentous fungal genera. The aflatoxin-producing Aspergillus flavus and A. parasiticus, and ochratoxigenic A. niger, A. ochraceus and A. carbonarius species are frequently measured in agricultural commodities (Leong et al., 2007). Molecular techniques have shown that there is a high biodiversity, but that taxa and taxonomy are difficult to discern based only on their morphological characteristics (Murakami, 1979; Al-Musallam, 1980). It is important to precisely identify and assign black Aspergillus occurring on coffee to taxonomic ranks because the toxin patterns of individual isolates differ and the fungi present in the field represent and define potential toxicological hazards. However, the taxonomy of Aspergillus section Nigri is confused and so far has not been totally resolved, especially within the A. niger aggregate. AlMusallam (1980) illustrated A. niger as an aggregate of two species, A. foetidus and A. niger, that are subdivided further into seven varieties, based on phenotypic and cultural criteria. There are numerous useful tools to discriminate mycotoxin-producing Aspergillus species (Schmidt et al., 2003), but it is still particularly difficult to differentiate between toxigenic and non-toxigenic strains of the identical species. Molecular studies are now providing useful data, which help clarify the identification and taxonomy of black Aspergillus. Such studies involve RFLPs of both nuclear and mitochondrial DNA, polymerase chain reaction (PCR)-based methods and phylogenetic analysis (Abarca et al., 2004; Geiser et al., 2007; Perrone et al., 2007; Samson et al., 2007). Furthermore, some black Aspergillus species have been described recently, for instance A. brasiliensis (Varga et al., 2007), A. ibericus (Serra et al., 2003), A. uvarum (Perrone et al., 2008), and A. vadensis (de Vries et al., 2005). Of these $A$. brasiliensis, A. ibericus and $A$. uvarum have also occasionally been found on grapes but they did not produce ochratoxin A (OTA).

Usual identification and quantification methods of food-borne fungi require multiple steps. They are time-consuming and often mycological expertise is required (Dao et al., 2005). Early detection of OTA-producing species is crucial in these strategies to prevent OTA entering the food chain (Dao et al., 2005; Niessen, 2007). DNA-based methods are an excellent choice for conventional identification techniques, because they are rapid, sensitive, specific, and allow accurate identification of fungal species (Geisen et al., 2004; Borman et al., 2008).

The main aim of the current research was to detect A. flavus, A. carbonarius and $A$. ochraceus, considered the main sources of OTA-contaminating commodities, particularly coffee and derivatives, in warm climates, and to use microsatellite-primed PCR (MP-PCR) typing of Aspergillus species collected from coffee beans.

\section{MATERIAL AND METHODS}

\section{Collection of samples}

Ten samples of green coffee beans were collected randomly from different markets in Ridyah, Saudi Arabia, during 2009. They were stored at $3-5^{\circ} \mathrm{C}$ to avoid any toxin formation or microbial contamination before analysis.

\section{Aspergillus isolation and identification}

The direct plating technique was used to assess the mycological quality of the samples 
(Pitt and Hocking, 1997). Fifty seeds (per each sample) were surface-disinfected with $1 \%$ sodium hypochlorite solution for $1 \mathrm{~min}$ and then rinsed in sterile distilled water three times. Five seeds were then placed onto the surface of agar plates containing potato dextrose agar (PDA) (Figure 1). All plates were incubated for 1 week at $25^{\circ} \mathrm{C}$ in the dark. On the last day of incubation, conidiophores from colonies of Aspergillus spp were directly transferred to malt extract agar slants and allowed to grow at room temperature for 7 days prior to transferring to other media for identification to species level. Each strain was identified according to the methods of Klich (2002) and Pitt and Hocking (1997). The investigation of cultural characteristics was carried out on colonies of the three Aspergillius species after grown on PDA, malt yeast agar and Sabouraud dextrose agar.

\section{Ochratoxin determination and quantification by HPLC}

The ochratoxin determination was performed according to the method described by Téren et al. (1996). OTA was extracted from $25 \mathrm{~g}$ of the sample with acetonitrile. The extract was cleaned up by passing it through an immuno-affinity column (OchraPrep, Code P 14B, RhôneDiagnostics Technologies Ltd., Spain), and the OTA was eluted with methanol:water:acetic acid (65:30:2), and separated by reverse-phase high performance liquid chromatography (HPLC) using a LiChrospher $100 \mathrm{RP}-18,5 \mu \mathrm{m}$ column 25 x $4.6 \mathrm{~mm}$ EcoPack (Merck, Portugal), with fluorescence detector and computing integrator Merck Hitachi (Compaq Deskpro); excitation and emission wavelengths were 333 and $460 \mathrm{~nm}$. The mobile phase was water:acetonitrile:acetic acid (102:96:2) filtered through a $0.22-\mu \mathrm{m}$ filter membrane, at a flow rate of $1.0 \mathrm{~mL} / \mathrm{min}$. OTA was quantified by using standard solutions (Sigma Ref. O-1877) to determine calibration curve and spiky samples for calculating recovery ratio. The tested samples were considered as negative if the OTA concentration was under $1 \mu \mathrm{g} / \mathrm{kg}$ (below the quantification limit). The quantification analysis was doubled per tested isolates.

\section{Fungal isolates for ochratoxin A production}

Collected isolates belonging to A. niger, A. ochraceus and A. carbonarius were tested for OTA production. OTA was assayed following the methodology described by Téren et al. (1996), with some modifications as follows: the isolates were grown in stationary cultures in 25 -mL quantities of YES medium ( $2 \%$ yeast extract, $15 \%$ sucrose) at $28^{\circ} \mathrm{C}$ for 10 days in the dark. After incubation, a portion of these culture media $(1 \mathrm{~mL})$ was mixed with $1 \mathrm{~mL}$ chloroform and centrifuged at $4000 \mathrm{~g}$ for $10 \mathrm{~min}$. The chloroform phase was transferred to a clean tube, evaporated to dryness and redissolved in $0.5 \mathrm{~mL}$ methanol. Then, OTA was detected according to the methods previously described.

\section{DNA extraction}

Fungal mycelium $(100 \mathrm{mg})$ was homogenized into fine powder in liquid $\mathrm{N}_{2}$. Pre-warmed (at $65^{\circ} \mathrm{C}$ ) $500 \mu \mathrm{L}$ DNA isolation buffer [SDS method (Cenis, 1992): $100 \mathrm{mM}$ Tris-HCl, $\mathrm{pH} 8.0,50$ mM Na $\mathrm{NDTA}_{2}$, pH $8.0,500 \mathrm{mM} \mathrm{NaCl}, 1.5 \% \mathrm{SDS}, 0.38 \%$ sodium bisulfite] was added to ground samples; also $5 \mu \mathrm{L}$ proteinase $\mathrm{K}(10 \mathrm{mg} / \mathrm{mL})$ was added and mixed well and incubated for $30 \mathrm{~min}$ at $37^{\circ} \mathrm{C}$ with irregular mixing every $3 \mathrm{~min}$. The microtube was centrifuged at $13,000 \mathrm{~g}$ for $15 \mathrm{~min}$ and the supernatant was transferred carefully into a new 1.5-mL Eppendorf tube. Sodium acetate 
solution $(130 \mu \mathrm{L}, 3 \mathrm{M}, \mathrm{pH} 5.52)$ was added and incubated at $-20^{\circ} \mathrm{C}$ for $20 \mathrm{~min}$. The Eppendorf tube was centrifuged at $8000 \mathrm{~g}$ for $4 \mathrm{~min}$. The superior aqueous phase was decanted into new centrifuge tubes and DNA was precipitated with $2 / 3$ volume of ice-cold isopropanol and kept at room temperature for $7 \mathrm{~min}$. DNA was pelleted down by centrifugation at $4^{\circ} \mathrm{C}$ for $10 \mathrm{~min}$ at 8000 $g$. The DNA pellet was cleaned twice with $70 \%$ ethanol $(700 \mu \mathrm{L})$ and centrifuged at $8000 \mathrm{~g}$ for 1 min, vacuum dried and dissolved in $100 \mu \mathrm{L}$ warmed TE buffer. Finally, $5 \mu \mathrm{L}$ RNAse A ( $20 \mathrm{mg} /$ $\mathrm{mL}$ ) was added and incubated at $37^{\circ} \mathrm{C}$ for $30 \mathrm{~min}$ (Bahkali et al., 2008).

\section{Microsatellite-primed PCR}

PCR products were obtained in a total volume of $25 \mathrm{~mL}$ with $20 \mathrm{ng}$ template DNA, 0.2 $\mathrm{mM}$ T3B and M13 primers (MWG, Germany), $200 \mathrm{mM}$ of each dNTP, 1 U Taq Polymerase (JenaBioscience, Germany) and $1 \mathrm{X}$ reaction buffer for the polymerase used. DNA and PCR mixture were amplified in a Techne TC-312 (Techne, Stone, UK) under the following conditions: initial denaturation at $94^{\circ} \mathrm{C}$ for $3 \mathrm{~min} ; 40$ cycles of denaturation at $94^{\circ} \mathrm{C}$ for $20 \mathrm{~s}$, annealing at $50^{\circ} \mathrm{C}$ for $1 \mathrm{~min}$, extension at $72^{\circ} \mathrm{C}$ for $20 \mathrm{~s}$, and a final extension at $72^{\circ} \mathrm{C}$ for $7 \mathrm{~min}$. Amplification products were resolved electrophoretically on $1.5 \%$ agarose gel in a $1 \mathrm{X}$ TAE buffer by loading $8 \mu \mathrm{L}$ into prepared wells. Gels were stained with ethidium bromide.

\section{Specific PCR assay}

PCR amplification was carried out using two sets of primers: OCRA1/OCRA2 (5'-CTTCCTTAGGGGTGGCACAGC-'3 and 5'-GTTGCTTTTCAGCGTCGGCC-'3, respectively) for A. ochraceus (Patiño et al., 2005). All amplification reactions were carried out in a final volume of $25 \mu \mathrm{L}$ containing $15 \mathrm{ng}$ template DNA, 20 pmol of each primer, 1X PCR buffer, $2 \mu \mathrm{M} \mathrm{MgCl}_{2}, 1 \mathrm{mM}$ dNTPs and $0.04 \mathrm{U} / \mu \mathrm{L}$ Taq DNA polymerase (Jena-Bioscience). PCRs were performed in a Techne TC-312 (Techne) PCR system.

\section{Gel documentation}

All agarose gels were stained with ethidium bromide $(1 \mu \mathrm{g} / \mathrm{mL}$ in distilled water) for $15 \mathrm{~min}$ at room temperature and inspected in transmitting UV light at $233 \mathrm{~nm}$, and photographed by Gel Documentation System (Uvitec, Cambridge, UK). The ImageForge software was employed for processing digital images of the gels.

\section{RESULTS}

\section{Morphological characterization}

Colonies of $A$. niger on PDA at $27^{\circ} \mathrm{C}$ are initially white, quickly becoming black with conidial production. Reverse is pale yellow and growth may generate radial fissures on the agar (Figure 1). Hyphae are septate and hyaline. Conidial heads are radiate initially, splitting into columns at maturity. The species is biseriate (vesicles produce sterile cells known as metulae that support the conidiogenous phialides). Conidiophores are long (400-3000 $\mu \mathrm{m})$, smooth and hyaline, becoming darker at the apex, and terminate in a globose vesicle $(30-75 \mu \mathrm{m}$ in diameter). 


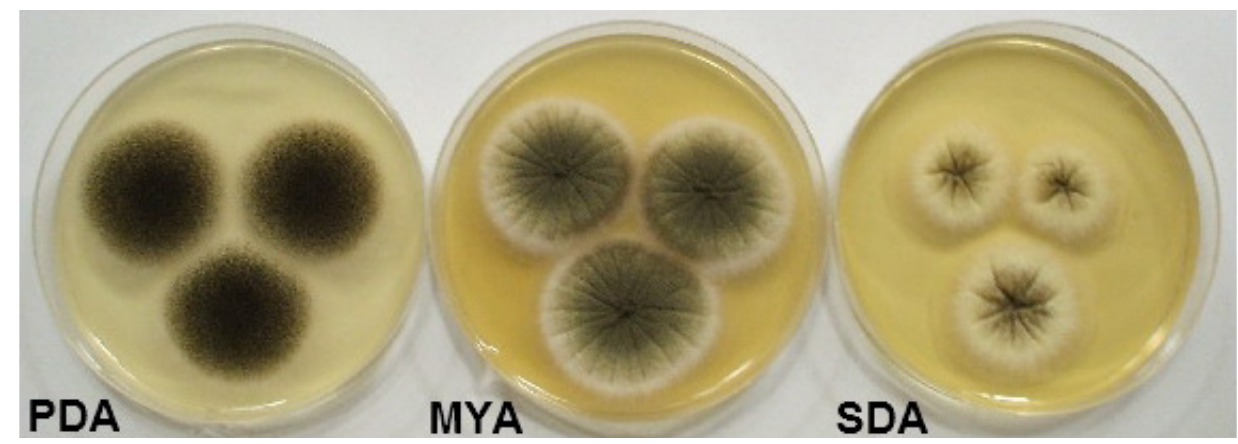

Figure 1. Cultural characteristics of Aspergillus niger grown on potato dextrose agar (PDA), malt yeast agar (MYA) and Sabouraud dextrose agar (SDA). Colonies on PDA black appressed mycelium, becoming grayish on MYA.

The results revealed the presence of potentially ochratoxigenic species in $90 \%$ of the isolates studied, among which $A$. niger was the species most frequently detected $(50 \%)$, followed by $A$. ochraceus (30\%). Moreover, this study confirmed that besides A. ochraceus, isolates of $A$. niger aggregate and $A$. carbonarius might be responsible for OTA contamination in green coffee. Nine isolates (90\%) of 10 isolates of Aspergillus species were OTA producers in culture. Toxin levels ranged from 2.12 to $0.15 \mu \mathrm{g} / \mathrm{g}$ of culture medium. Aspergillus niger was the species with the highest percentage of OTA-producing isolates (Table 1).

Table 1. Ochratoxin A (OTA) production capabilities of Aspergillus isolates used in this study and the occurrence of PCR amplification product with the primer pair OCRA1/OCRA2.

\begin{tabular}{llcc}
\hline Isolate code & Aspergillius species & OTA quantity $(\mu \mathrm{g} / \mathrm{g})$ & OCRA1/OCRA2 $^{\mathrm{a}}$ \\
\hline Asp-KSU1 & Aspergillius niger & 1.22 & $\circ$ \\
Asp-KSU2 & Aspergillius niger & 2.12 & $\circ$ \\
Asp-KSU3 & Aspergillius niger & 0.15 & $\circ$ \\
Asp-KSU4 & Aspergillius niger & 0.20 & $\circ$ \\
Asp-KSU5 & Aspergillius niger & 0.00 & $\circ$ \\
Asp-KSU6 & Aspergillius carbonarious & 1.70 & $\circ$ \\
Asp-KSU7 & Aspergillius carbonarious & 0.82 & $\circ$ \\
Asp-KSU8 & Aspergillius carbonarious & 0.51 & $\bullet$ \\
Asp-KSU9 & Aspergillius ochraceus & 0.74 & $\bullet$ \\
Asp-KSU10 & Aspergillius ochraceus & \\
\hline
\end{tabular}

${ }^{\mathrm{a}}$ The presence or absence of species-specific amplicon is indicated by a filled or open circle for each set of primers.

MP-PCR was used to identify genetic variation among Aspergillus species isolates. The dendrogram obtained from cluster analysis of the MP-PCR fingerprints revealed a great deal of heterogeneity among the isolates as forming two clusters. Intraspecific similarity among Aspergillus isolates ranged from 72 to $92 \%$. An example of a typical MP-PCR profile is given in Figure 2. The three species were grouped into three major patterns.

Aspergillus isolates listed in Table 1 were assayed for amplification using the primer pair OCRA1 and OCRA2. A single segment of about $400 \mathrm{bp}$ was only amplified when genomic DNA from A. ochraceus isolates was used (Figure 3). No product was observed with genomic DNA from the Aspergillus isolates other than A. ochraceus or in the case of other genera (Table 1). 


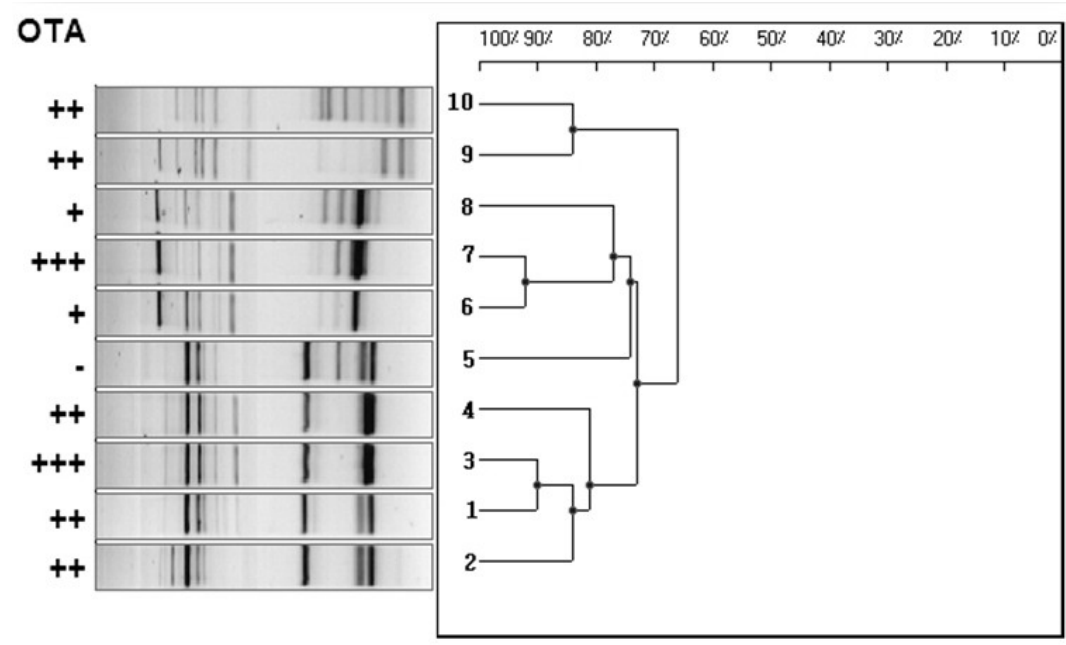

Figure 2. Combined cluster analysis derived from MP-PCR analysis of 10 Aspergillus spp isolates using two MPPCR primers. OTA $=$ ochratoxin A. Toxigenic $(+)$ and non-toxigenic $(-)$.

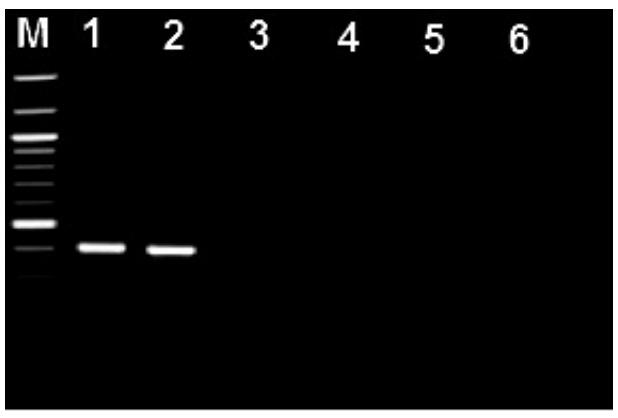

Figure 3. Agarose gel of PCR with the OCRA1/OCRA2 primer pair and two Aspergillus ochraceus isolates (lanes 1 and 2), A. niger (lanes 3 and 4) and A. carbonarius (lanes 5 and 6 ). $\mathrm{M}=100$-bp DNA molecular weight ladder (Jena Bioscience).

\section{DISCUSSION}

Some species belonging to the genus Aspergillus are potential producers of OTA, a mycotoxin with nephrotoxic, immunosuppressive, teratogenic, and carcinogenic effects. It has been suggested that $A$. carbonarius could be the major cause of OTA production in grapes and derivatives (Cabañes et al., 2002) mainly in the Mediterranean region (Serra et al., 2003), and that $A$. ochraceus could be the main source of OTA in coffee (Logrieco et al., 2003; Taniwaki et al., 2003). The aim of the present study was to identify the contaminate species of Aspergillus found inside of coffee beans. The collected samples were from different hypermarkets located in the Riyadh city and differed in maturity stage and drying status.

The most frequently isolated fungal species from coffee beans was A. flavus (50\%) followed by $A$. carbonarius. A. flavus strains (80\%) were positive for OTA production. Our 
finding is in harmony with results obtained by Pardo et al. (2004). Concerning the ability of A. carbonarius and A. ochraceus species to produce OTA, all the isolates were able to produce this mycotoxin. These data are similar to those found in coca bean (Sánchez-Hervás et al., 2008). Taniwaki et al. (2003) showed that A. carbonarius, A. niger and A. ochraceus are the major OTA producer species found in Brazilian coffee bean samples. Based on RAPD (random amplified polymorphic DNA) and AFLP (amplified fragment length polymorphism) markers, specific primers for PCR detection of A carbonarius (Schmidt et al., 2004; Susca et al., 2007) and $A$. ochraceus (Fungaro et al., 2004) were recently developed. A pair-wise similarity matrix was calculated using the Pearson correlation method and a dendrogram was generated by the unweighted pair group method with arithmetic mean (UPGMA), illustrating four different clustered groups: the uniseriate cluster (I), the A. carbonarius cluster (II), and the two $A$. niger aggregate clusters.

The PCR assay developed for A. ochraceus identificationiimppneetchildtere axabsøksocsuccessfully applied for detecting an amplicon of $400 \mathrm{bp}$. The specificity and sensitivity of the assay reported by Patiño et al. (2005) were based on a single copy target region of $A$. ochraceus. It was used to detect OTA-producing fungi in raw cultures such as coffee and to prevent OTA from entering the food chain. Detection of these fungi, in the case of coffee, is particularly critical around harvest time, when contamination levels and OTA production is considered high. Further studies are needed to develop molecular markers to distinguish toxigenic and non-toxigenic strains of ochratoxigenic Aspergillus.

\section{ACKNOWLEDGMENTS}

Research supported by a grant from the Incubating Graduate Project Program, King Saud University. The authors gratefully acknowledge the partial financial support of the Distinguished Scientist Fellowship Program (DSFP), King Saud University.

\section{REFRENCES}

Abarca ML, Accensi F, Cano J and Cabanes FJ (2004). Taxonomy and significance of black aspergilli. Antonie Van Leeuwenhoek 86: 33-49.

Al-Musallam A (1980). Revision of the Black Aspergillus Species. PhD thesis, State University Utrecht, The Netherlands. Bahkali AH, Abd-Elsalam KA, Moslem MA and Al-Khedhairy AA (2008). In-house protocol for isolation of restrictable and amplifiable genomic DNA from plants, fungi and bacteria. Genes Genomes Genomics 2: 77-88.

Borman AM, Linton CJ, Miles SJ and Johnson EM (2008). Molecular identification of pathogenic fungi. J. Antimicrob. Chemother. 1 (Suppl 61): i7-i12.

Cabañes FJ, Accensi F, Bragulat MR, Abarca ML, et al. (2002). What is the source of ochratoxin A in wine? Int. J. Food Microbiol. 79: 213-215.

Cenis JL (1992). Rapid extraction of fungal DNA for PCR amplification. Nucleic Acids Res. 20: 2380.

Dao HP, Mathieu F and Lebrihi A (2005). Two primer pairs to detect OTA producers by PCR method. Int. J. Food Microbiol. 104: 61-67.

de Vries RP, Frisvad JC, van de Vondervoort PJ, Burgers K, et al. (2005). Aspergillus vadensis, a new species of the group of black aspergilli. Antonie Van Leeuwenhoek 87: 195-203.

Fungaro MH, Vissotto PC, Sartori D, Vilas-Boas LA, et al. (2004). A molecular method for detection of Aspergillus carbonarius in coffee beans. Curr. Microbiol. 49: 123-127.

Geisen R, Mayer Z, Karolewiez A and Farber P (2004). Development of a real time PCR system for detection of Penicillium nordicum and for monitoring ochratoxin A production in foods by targeting the ochratoxin polyketide synthase gene. Syst. Appl. Microbiol. 27: 501-507.

Geiser DM, Klich MA, Frisvad JC, Peterson SW, et al. (2007). The current status of species recognition and identification 
in Aspergillus. Stud. Mycol. 59: 1-10.

Klich MA (2002). Identification of Common Aspergillus Species. Centraalbureau Voor Schimmelcultures, Utrecht.

Leong SL, Hien LT, An TV, Trang NT, et al. (2007). Ochratoxin A-producing aspergilli in Vietnamese green coffee beans. Lett. Appl. Microbiol. 45: 301-306.

Logrieco A, Bottalico A, Mulé G, Moretti A, et al. (2003). Epidemiology of toxigenic fungi and their associated mycotoxins for some Mediterranean crops. Eur. J. Plant Pathol. 109: 645-667.

Murakami H (1979). Some experimental methods and cultural characteristics of the black aspergilli. Taxonomic studies on Japanese Industrial strains of the Aspergillus. J. Soc. Brew. 74 (Part 26): 323-327.

Niessen L (2007). Current Trends in Molecular Diagnosis of Ochratoxin A Producing Fungi. In: Mycotechnology: Present Status and Future Prospects (Rai M, ed.). I.K. International Publishing House, New Delhi, 84-105.

Pardo E, Marin S, Ramos AJ and Sanchis V (2004). Occurrence of Ochratoxigenic Fungi and Ochratoxin A in Green Coffee from Different Origins. Food Sci. Technol. Int. 10: 45-49.

Patiño B, González-Salgado A, Gonzalez-Jaen MT and Vázquez C (2005). PCR detection assays for the ochratoxinproducing Aspergillus carbonarius and Aspergillus ochraceus species. Int. J. Food Microbiol. 104: 207-214.

Perrone G, Susca A, Cozzi G, Ehrlich K, et al. (2007). Biodiversity of Aspergillus species in some important agricultural products. Stud. Mycol. 59: 53-66.

Perrone G, Varga J, Susca A, Frisvad JC, et al. (2008). Aspergillus uvarum sp nov., an uniseriate black Aspergillus species isolated from grapes in Europe. Int. J. Syst. Evol. Microbiol. 58: 1032-1039.

Pitt JI and Hocking AD (1997). Fungi and Food Spoilage. Vol. II. Blackie Academic and Professional, London.

Samson RA, Noonim P, Meijer M, Houbraken J, et al. (2007). Diagnostic tools to identify black aspergilli. Stud. Mycol. 59: 129-145.

Sánchez-Hérvas M, Gil JVV, Bisbal F, Rámon D, et al. (2008). Mycobiota and mycotoxin producing fungi from cocoa beans. Int. J. Food Microbiol. 125: 336-340.

Schmidt H, Ehrmann M, Vogel RF, Taniwaki MH, et al. (2003). Molecular typing of Aspergillus ochraceus and construction of species specific SCAR-primers based on AFLP. Syst. Appl. Microbiol. 26: 138-146.

Schmidt H, Taniwaki MH, Vogel RF and Niessen L (2004). Utilization of AFLP markers for PCR-based identification of Aspergillus carbonarius and indication of its presence in green coffee samples. J. Appl. Microbiol. 97: 899-909.

Serra R, Abrunhosa L, Kozakiewicz Z and Venancio A (2003). Black Aspergillus species as ochratoxin A producers in Portuguese wine grapes. Int. J. Food Microbiol. 88: 63-68.

Susca A, Stea G, Mule G and Perrone G (2007). Polymerase chain reaction (PCR) identification of Aspergillus niger and Aspergillus tubingensis based on the calmodulin gene. Food Addit. Contam. 24: 1154-1160.

Taniwaki MH, Pitt JI, Teixeira AA and Iamanaka BT (2003). The source of ochratoxin A in Brazilian coffee and its formation in relation to processing methods. Int. J. Food Microbiol. 82: 173-179.

Téren J, Varga J, Hamari Z, Rinyu E, et al. (1996). Immunochemical detection of ochratoxin A in black Aspergillus strains. Mycopathologia 134: 171-176.

Varga J, Kocsube S, Toth B, Frisvad JC, et al. (2007). Aspergillus brasiliensis sp nov., a biseriate black Aspergillus species with world-wide distribution. Int. J. Syst. Evol. Microbiol. 57: 1925-1932. 